Available online at GSC Online Press Directory

GSC Biological and Pharmaceutical Sciences

e-ISSN: 2581-3250, CODEN (USA): GBPSC2

Journal homepage: https://www.gsconlinepress.com/journals/gscbps

(RESEARCH ARTICLE)

\title{
Comparative whitefly vector density and bean disease incidence on local and hybrid varieties in semi-arid Kenya
}

\author{
Kamonzo Jedidah K. ${ }^{1}{ }^{*}$, Mutisya Daniel L. ${ }^{2}$, Muli Benjamin K. ${ }^{1}$ and Nguluu Simon N. ${ }^{1}$ \\ ${ }^{1}$ South East Kenya University, P.O. Box 170-90200, Kitui, Kenya. \\ ${ }^{2}$ Kenya Agricultural \& Livestock Research Organization, P. O. Box 340. 90100, Machakos, Kenya.
}

Publication history: Received on 25 July 2018; revised on 25 November 2018; accepted on 03 December 2018

Article DOI: https://doi.org/10.30574/gscbps.2018.5.3.0071

\begin{abstract}
The dry bean, Phaseolus vulgaris (L.) production is constrained by various factors in the environment. A survey was carried out to determine incidence of various foliage diseases and possible influence by whitefly vectors among other environmental factors on bean grain yield. Highest farmer cultivar preference was a tie of improved KAT Bean 1 (B1) and local cultivar (Mwitemia) at 24\% as total of each category. Production level was 0.3-1.6 $\mathrm{t} \mathrm{ha}^{-1} \mathrm{per}_{\text {farm. Dominant }}$ whitefly species was Bemisia tabaci (Genn.) in over $90 \%$ of the farms. Laboratory analyses showed that disease incidence among the varieties showed improved varieties bearing highest incidence of both fungal and viral diseases compared to the local cultivars. Disease incidence showed little influence on bean grain yield. The updated information here is useful to breeding programmes to focus on local cultivars for higher disease-tolerant bean genotypes.
\end{abstract}

Keywords: Improved; Local; Cultivars; Whitefly; Yield; Diseases

\section{Introduction}

The common dry bean, Phaseolus vulgaris (L.) is the most important food legume for direct human consumption in the world [1-2]. Production occurs in a wide range of cropping systems and environments spanning across regions as diverse as Latin America, Africa, the Middle East, China, Europe, the United States, and Canada [3-4]. In the Latin America, the leading bean producer and consumer, the crop occupies some unique niche of traditional and food security for the low income people particularly in Brazil, the Andean Zone, Asia, Central America, and some Caribbean countries [4-5, 7-8]. However, the highest per capita consumption in the world occurs in eastern Africa especially in the Great Lakes Region [9-11]. Beans are also an important source of dietary protein in Kenya, Tanzania, Malawi, Uganda, and Zambia [12].

The Food and Agriculture Organization of the United Nations (FAO) reported that some European data on production area for common beans are simply rough estimates and consequently yields are underestimated because of the combination of data from mixed cropping and monoculture [4-5]. World common-bean production can be conveniently grouped into specific regions with the most important being Brazil, Mexico, and eastern African highlands [7-8]. Beans are a major staple in these regions which together contribute to half of the world's production [13-14]. The USA and the Southern Cone of South America are major producers for export markets [15]. In most regions of the developing world, growth in bean production has tailed off in the last decade [16]. Brazil, eastern Africa, the African Great Lakes Region, southern Africa, and the Andean zone all experienced slower production growth during 1972-74 to 1982-84 than during the previous ten-year period $[12,14]$. In the present decade, human population growth has outstripped that of bean production in all four regions $[4,11]$.

\footnotetext{
${ }^{*}$ Corresponding author

E-mail address: jedidahkamonzo@gmail.com
}

Copyright (C) 2018 Author(s) retain the copyright of this article. This article is published under the terms of the Creative Commons Attribution Liscense 4.0. 
Comparison of annual bean production growth rates in yields and area sown provide insights on the causes of declining growth among many bean producers. In general, there has been little improvement in bean yield due to various constraints of production [12]. This is true both for slow population growth regions such as the Andes and southern Africa, and for rapid growth regions such as the Southern Cone and West Asia [4, 7]. Area expansion in marginal agricultural lands has been the major source of production growth in Brazil, the African Great Lakes Region, eastern and southern Africa, the Southern Cone, and Central America [14, 16]. Nevertheless, increased climate variability has contributed to low production besides biotic factors [17].

Worldwide, it is reported that there are over 1500 whitefly species known in approximately 126 genera [18]. Bemisia tabaci is a species complex that is globally distributed [18] and important because a number of the species ecotypes that make up the complex are known to damage commercially important plant species either through direct feeding or through the transmission of more than 150 plant viruses primarily belonging to the genus Begomo virus (Family: Geminiviridae) [19-21]. It has, therefore become important to control whiteflies with the aim of reducing virus transmission and agronomic losses on crops like beans. Nevertheless, little information exists on level of viral diseases causing bean yield losses and contribution by whitefly vectors in the marginal areas of Kenya and the larger Great Lakes Region. Moreover, a lot of information is available from the Americas and Asian countries of yield losses due to whiteflyviral disease transmission $[6,20]$.

The present work aimed to identify the distribution of different species of whitefly in one semi-arid region of eastern Kenya, comparing the insect density and subsequent yield levels. The work compared disease symptoms on local and hybrid bean varieties in Kitui County and focused to contribute information on most appropriate variety to grow in those marginal areas.

\section{Material and methods}

\subsection{Farm survey on production}

The survey covered wetter midlands of Central Kitui County in 2016 and 2017. A total of 22 farms was covered in two bean production sites of Changwinya West Ward and Kitui East Ward (Fig. 1). Changwiya is 5 Km west of Kitui Town while Kitui East ward is about $6 \mathrm{Km}$ in the eastern side. Kitui is 180 Kilometres east of Nairobi City of Kenya. A questionnaire was used to interview farmers on bean production acreage, type of cropping system, pest and diseases, pesticide and fertilizer use by farmers on bean production. Repeat visits in the identified plots enabled collection of data at harvest of crop plots. A geographical position service (GPS) device was used to mark each farm position within the locality. Rainfall data of the production period was secured from Kenya Agricultural and Livestock Sub-Centre of Ithookwe which is centrally placed at 2 Kilometres west of Kitui Town.

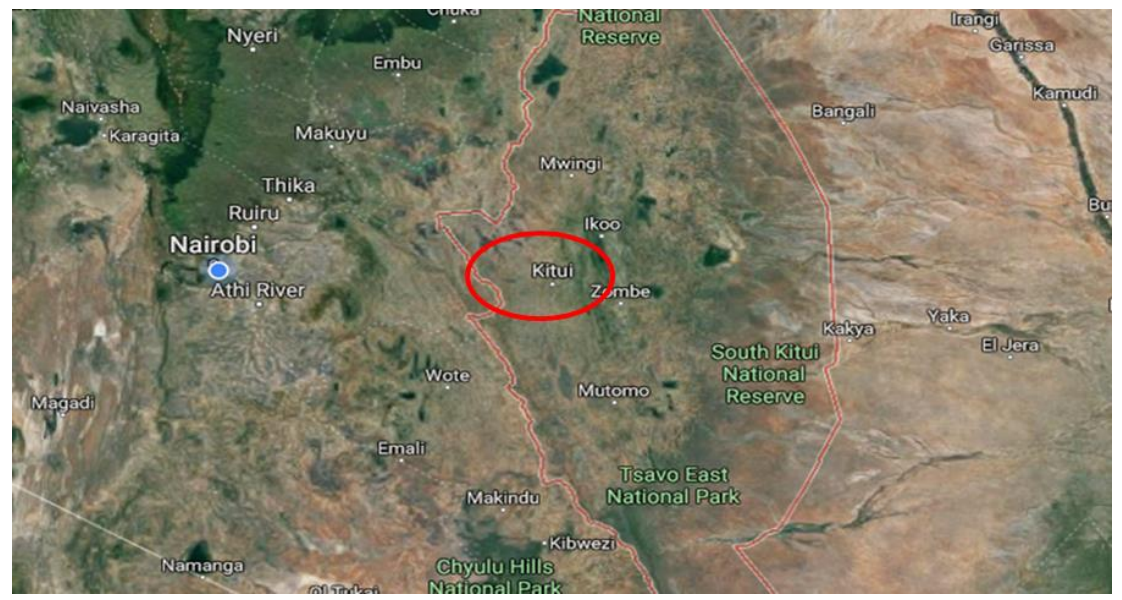

Figure 1 Whitefly survey sites during the production bean seasons of 2016-2017

\subsection{Whitefly specimen collection}

In each farm whitefly specimens found on bean leaves were collected by use of either an aspirator or by hand picking with ethanol-wet hair brushes (size 000) and secured in 70\% alcohol vials where a maximum of 10 individual adults were preserved. Adjacent weed plants were noted for relatedness to bean plant Family Fabae. Any other major insect 
pest on bean plants was scored for comparative review of disease vector on beans. A quadrat of $1 \mathrm{~m}^{2} \mathrm{was}$ used to mark out net sample area in each random sample plot per farm. The quadrat sampling was repeated five times per farm plot.

\subsection{Laboratory specimen identification}

Whitefly specimen collected from each locality and preserved in $70 \%$ ethanol vials, were identified by using the procedure by Martin [22] where upper and lower compound eyes (Ocelli structures) on the whitefly specimens were observed for their separated nature as is the case of Trialeuroides vaporariorum (while in Bemisia tabaci the ocelli body appears connected into one block with single constriction gap. A further species differentiation was carried out by taking count of the stout setae on the hind leg of the whitefly on mesototibia part where for B. tabaci it was 2-3 comb brushes and T. vaporariorum was 4-7 metatibial combs [22]. Identified specimens (on glass slide mounts) were preserved in the Kenya Agricultural and Livestock Insectary for reference.

\subsection{Laboratory disease identification}

Bean disease lesions were identified based on visual symptoms on diseased bean leaves and by isolation and identification of fungal and bacterial pathogens from symptomatic bean leaf tissues on culture media. Viral symptoms were identified visually and confirmed by reference to bean diseases caused by viruses in bean literature reference. Fungal isolations were carried out growing the pathogens on Potato Dextrose Agar amended with antibiotic (streptomycin and neomycin) while bacteria were isolated on selective media YDC (yeast extract-dextrose- $\mathrm{CaCO}_{3}$ ). Fungi were identified based on spore characters on PDA while bacteria were identified based on colour on YDC.

\subsection{Statistical analyses}

The farmer cultivar preference, whitefly density and disease incidence were presented in percentages while temperature and rainfall amounts in the two production months (April and May 2016 and similarly in 2017) were graphed in MS Excel (2013). Bean production acreage and yield levels were subjected to analysis of variance by Fisher's Least Significance Difference (LSD) Test at P= 0.05), using SAS software on General Linear Model (GLM) PROC.

\section{Results}

\subsection{Farmer cultivar preference}

Out of the 22 farms sampled, 23\% were men and 77\% were women producers indicating that the latter valued bean production than the former. Highest cultivar preference was a tie of KAT Bean 1 (B1) of improved variety category and Mwitemania a local cultivar at $24 \%$ as total of each category (Table 1). This meant that combing both cultivars B1 and Mwitemania, accounted for $48 \%$ of bean production in the two wards. The least preferred cultivar was Wairimu grown in Kitui East only. Other local cultivars appeared as isolated preference by specific farmers in the areas of production as indicated in Table 1.

Table 1 Mean cultivar preference (\%) within Central Kitui County in 2016and 2017seasons

\begin{tabular}{|c|c|c|c|c|c|c|c|}
\hline \multirow[t]{3}{*}{ Ward } & \multicolumn{7}{|c|}{ Farmer cultivar preference (\%) } \\
\hline & \multicolumn{4}{|c|}{ Improved varieties } & \multicolumn{3}{|c|}{ Local cultivars } \\
\hline & Rosecoco & B1 & Nyayo & Mwezi-moja & Wairimu & Kamwithokya & Mwitemania \\
\hline Changwithya & 13 & 11 & 12 & 8 & 0 & 3 & 16 \\
\hline Kitui East & 3 & 13 & 5 & 0 & 3 & 5 & 8 \\
\hline Total (\%) & 16 & 24 & 17 & 8 & 3 & 8 & 24 \\
\hline
\end{tabular}

The rainfall pattern was low and poorly distributed in the long rainfall (LR) period in 2016 and improved slightly in 2017. A daily mean rainfall amount of $8.1 \pm 28.3 \mathrm{~mm}$ was recorded for the two production periods. It was noted that the month of May was cooler than the April during the production periods. Temperature range in April was $22 \pm 2$ while May was $20 \pm 3{ }^{\circ} \mathrm{C}$. An improvement on amount of rainfall was scored in the subsequent short rain (SR) period of October-December 2016 to January-February 2017. The daily mean rainfall score $12.1 \pm 9.3 \mathrm{~mm}$ was recorded for the production period. Temperature range in November was $23.2 \pm 2$ and January 2017 was $23.8 \pm 3^{\circ} \mathrm{C}$. 
There was no significant difference of altitude among the two ward locations, where Changwithya West and Kitui East were 1166.3 and $1024.0 \mathrm{~m}$ above sea level (Table 2). Mean bean production acreage during the two seasons was significantly in Kitui East than Changwithya at 1.6 and 0.3 /ha respectively. Bean production system showed farmers preferred maize intercropping in some cases adding cassava and pigeonpea or passion fruit crops. Kitui East alternated passion fruit intercrop with maize in bean production systems. Only one farmer reported input of mineral fertilizer (Kitui East), though nearly all farms had both animal and compost manure amendments applied.

Table 2 Plot acreage, altitude, inter crop systems of bean production in Central Kitui in 2016

\begin{tabular}{llll}
\hline Ward & Altitude (m) & Acreage (ha) & Intercrop system \\
\hline Changwinya West & $1166.3^{\mathrm{A}}$ & $0.3^{\mathrm{B}}$ & Maize, cowpea, cassava \\
Kitui East & $1024.0^{\mathrm{A}}$ & $1.6^{\mathrm{A}}$ & Maize, pigeon pea, passion fruit \\
SE & 231.3 & 2.4 & \\
LSD & 219.8 & 2.4 & \\
\hline
\end{tabular}

Indicated similar superscript letters denote no parameter variable significant difference (Fisher's Least Significant Difference Test, df $=1,10$ ) at $5 \%$ level.

\subsection{Whitefly species diversity}

Whitefly species identified in the laboratory were mainly two, T.vaporariorum and B. tabaci. In the two wards Changwithya had no score of T.vaporariorum while Kitui East had only two specimens of the species in one field plot, a 4.5\%incidence (Fig. 2). Highest density B. tabaci was observed in Changwithya West ward at close to 2 whiteflies per field plot of $1 \mathrm{~m}^{2}$.No other major insect pest was found on most bean plots besides a few species of aphids on isolated plants.

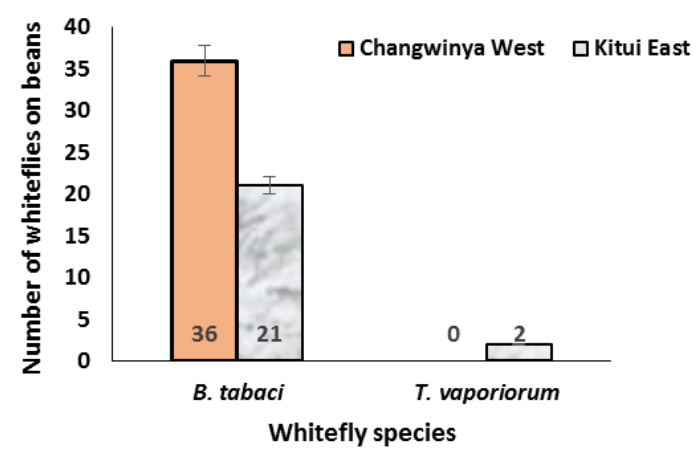

Figure 2 Comparative whitefly species diversity and abundance in Changwithya West and Kitui East Wards

\subsection{Diseases identity}

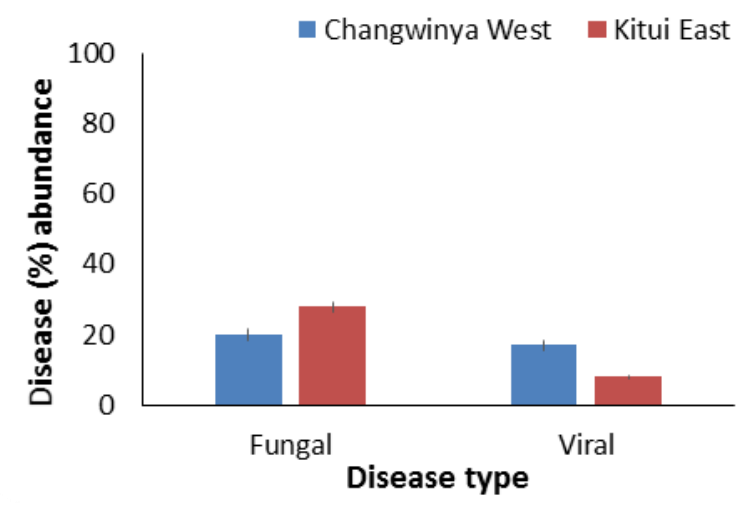

Figure 3 Visual estimation of fungal and viral diseases in Changwithya West and Kitui East wards of varied whitefly density infestations 
Field visual estimate of fungal diseases were 20 and 28\% for Changwithya West and Kitui East respectively (Fig.3). Likewise, viral disease incidence was 17 and 8\% respectively for Changwithya and Kitui East, respectively. This was symptomatic lesions at field observations on the plant leaves were evident and the participating farmers could easily recognize the disease symptoms. The impact of the disease incidence to yield loss could not be induced from the symptoms and perceived loss.

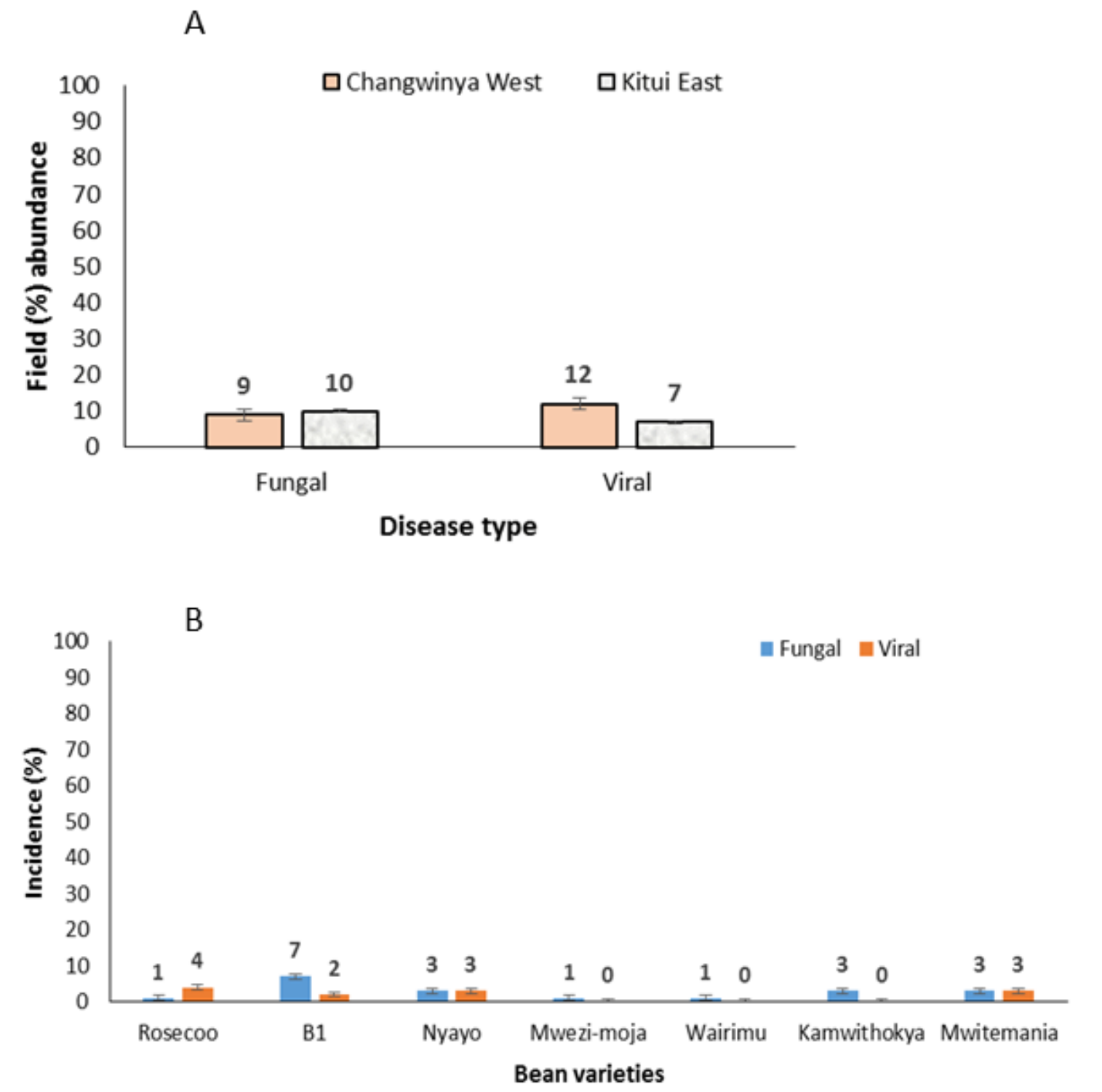

Figure 4 (A and B) Mean cultivar disease incidence on bean crop in Kitui (2016 and 2017)

After laboratory analyzes, disease incidence among the varieties indicated a scenario where improved varieties had higher incidence of both fungal, bacterial and viral diseases compared to the local cultivars (Fig.4). Mwezi-moja had least disease incidence of $1 \%$ while Rosecoco, B1 and Nyayo with $\geq 5 \%$ of fungal diseases, identified as Altenaria and Phoma species as common ones on the leaf dead lesions. The bacterial diseases found on the leaves were Pseudomonas spp, grouped together in the fungal lesions. The local cultivar with least incidence was Wairimu indicating $1 \%$ fungal disease occurrence, mainly being Altenaria species. The local variety bearing highest viral disease was Mwitemia at 3\%, of Bean Golden Yellow Mosaic Virus (BGYMV). Nevertheless, none of the varieties had higher than 10\% incidence of combined fungal and viral diseases. 


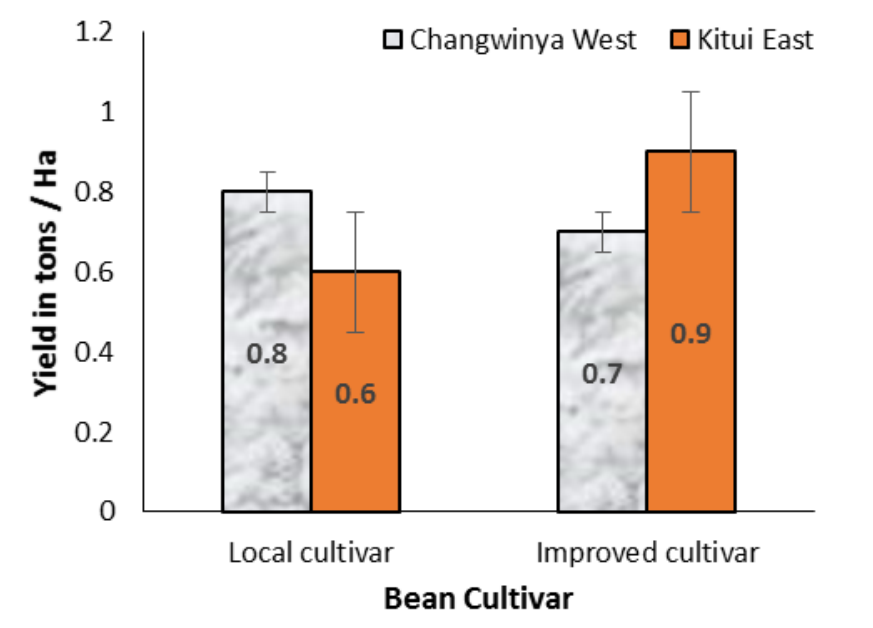

Figure 5 Bean varietal yield difference at two different wards in Central Kitui County 2016-17

Varietal yield difference was significantly $(p<0.05)$ greater in Changwithya West with the improved varieties being at 0.9 tons/ha, followed by local cultivars at 0.8 tons /ha in same ward (Fig.5). The least yield occurred in Kitui East of the local cultivars at 0.6 tons /ha. Disease incidence showed little influence on varieties where Rosecoco, B1, Mwezi-moja and Nyayo (improved category) had highest disease lesions, leading with highest yield (0.9 tons /ha) in Kitui East, comparable to 0.7 tons /ha in Changwithya West.

\section{Discussion}

The results of the present study showed that whitefly species infesting bean crop in the specified semi-arid land of Kitui to be B. Tabaci. As the known viral disease vector, B. tabaci was highest in Changwithya Ward which incidentally had twice of the disease incidence at $17 \%$ of the bean golden mosaic virus (BGMV) from visual identification. Various pests and diseases have been reported on bean crop [23]. No direct correlation could be drawn from the present data as considerations for site disease inoculum in terms of wild genotypes and Fabae types of plant family was not confirmed. Furthermore, actual disease incidence confirmed on the laboratory identification was low at less than $10 \%$ on all varieties as results from the laboratory analyses showed. The highest dry bean yield was on improved varieties at $0.9 \mathrm{t}$ ha $^{-1}$ in Kitui East, and closely similar to $0.7 \mathrm{t} \mathrm{ha}^{-1}$ in Changwithya West. Conversely, little yield difference was notable between improved and local cultivars as the latter scored 0.6 and $0.8 \mathrm{t} \mathrm{ha}^{-1}$ on local cultivars at Kitui East and Changwithya Wards respectively. It appeared that poor and irregular rainfall amounts contributed much to the low yields in comparison to the low disease incidence and absence of major pest insect.

The common agronomic practice observation showed that most farmers were not using mineral fertilizers, and the irregular rainfall distribution could be viewed as some combined factors leading to low bean production in terms of farmer own input and environmental effects [12,24]. Number of women participating in producing beans was higher than men at $77 \%$ with the majority growing improved varieties B1, Rosecoco and Nyayo at 16,24 and $17 \%$ variety preference, respectively. Of the local varieties Mwitemania had the highest category preference at $24 \%$ as a total from the two sites. Farmer bean variety preference is foremost determined by market which again is a product of various attributes like fast cookability and colour of the seed among other attributes [14].

Most improved varieties released to farmers like B1, Rosecoco and Nyayo have strong attractive red colour-shades as well as being of popular demand for their average fast cookability and palatability for local consumption [25-26]. Women have various ways in which they are involved in trade with beans and could explain why even in marginal area like Kitui County the crop production is popular. Mauyoet al. [13] reported on continued livelihood of bean trade between Kenya and Uganda whenever a short fall of the grain occurs across the border at Busia and Malava border points. As per the present study, bean crop production acreage levels indicated that Kitui East led with highest at 1.6 ha while Changwithya Ward had only 0.3 ha. The most preferred intercrop system was maize-bean which is practiced by most farmers in eastern Kenya reported that smallholder farmers prefer maize-bean production systems over pure stands due to higher yield value from inter-cropping [27]. The ensuing advantage of increased yield of maize production even when no fertilizer used due to soil fertility improvement by the legume was the driving advantage. This practice is common in eastern Kenya where oxen ploughing is preferred for reduced drudgery in general crop production. 


\section{Conclusion}

As the results indicated the fungal and viral diseases incidence was higher on improved varieties than the local ones. The only identifiable viral disease was the Bean Golden Yellow Mosaic Virus (BGYMV) which needed to be subjected to molecular analysis for correct Begomo viruses identification. This would suitably need sampling on wild plant species as well to pinpoint source of wild inoculum. Breeding programmes could benefit by sourcing for disease-resistant genetic material from the local cultivars.

\section{Compliance with ethical standards}

\section{Acknowledgments}

Mr. Henry S. Nzioki, the pathologist at KALRO-Katumani is acknowledged for laboratory processing and identification of the disease pathogens on bean leaves. Also Mr. John Kamau Ndegwa is acknowledged for save driving of Crop Protection vehicle taking the survey team to Central Kitui County and back to Katumani during the production seasons of 2016 to 2017.

\section{Disclosure of conflict of interest}

Daniel L. Mutisya, Jedidah K. Kamonzo and Benjamin K. Muli conceived the research idea and Simon N. Nguluu edited the proposed draft. The team; D. L. Mutisya, J. K. Kamonzo and B. K. Muli carried out the study survey. D. L. Mutisya, N. Nguluu, J. K. Kamonzo and B. K. Muli analyzed the data and wrote the paper. The authors declare no conflict of interest.

\section{References}

[1] Leterme P and Munõz LC. (2002). Factors influencing pulse consumption in Latin America. British Journal of Nutrition, 88(3), 251-254.

[2] Woodward I, Skrbis Z and Clive B. (2008). Altitudes towards globalization and cosmopolitanism: cultural diversity, personal consumption and national economy. British Journal of Sociology, 59(2), 207-226.

[3] Van Schoonhoven A and Voysest O. (1989). Common bean in Latin America and their constraints. On: Bean production in the Tropics; $2^{\text {nd }}$ Edition. Schwartz H.P. and Postor-Corrales MA. (eds.) - Centro Internacional de Agricultura Tropical (CIAT), Cali, Colombia, 33-59.

[4] FAO (2015). Food Agriculture Organization. Statistics available at www.fao.org/news/archive/news-bydate/2015/en

[5] Cardona C, Kornegay J, Posso CE, Morales F and Ramirez H. (1990). Comparative value of four arcelina variants in the development of dry bean lines resistant to Mexican bean weevil. Entomological Experiment Application 56(2), 197-206.

[6] Singh SP. (1991). Breeding for seed yield. On: Common beans. Research for Crop Improvement. In: van Schoonhoven A. and Voysest O. (eds.) CAB Internacional in association with Centro Internacional de Agricultura Tropical (CIAT), Cali, Colombia, 383-429.

[7] Xiaomong W. (1997). Germplasm resources, production and main biotic problems of dry bean (Phaseolus vulgaris L.) in China. Proceedings of Seminar by Centro Internacional de Agricultura Tropical (CIAT); 13 ${ }^{\text {th }}$ June, 1997, Cali Colombia, 13-16.

[8] Voysest 0 and Dessert M. (1991). Breeding for seed yield. On: Common beans. Research for Crop Improvement. In: van Schoonhoven A and Voysest O. (eds). CAB International in association with Centro Internacional de Agricultura Tropical (CIAT), 119-159.

[9] Makini FW. (1994). Bean production and constraints with emphasis on diseases in Kenya. In: Danial D. L. (ed). Proceedings for Regional Workshop for eastern, central and southern Africa, Nairobi, Kenya.Ministry for Dev. Cop. (DGIS). Netherlands, 104-109.

[10] Opio Fand Male-Kayiwa S. (1994). The status of bean breeding in Uganda. On: Breeding for disease resistant with emphasis on durability. Proceedings of Regional workshop for eastern, central and southern Africa: $2^{\text {nd }}-6^{\text {th }}$ Oct. 1994, Nairobi Kenya. In: Danial DL. (ed). Ministry for Development Cooperation (DGIS)-Netherlands, 110-113. 
[11] Korir MK, Odhiambo MO, Iruria DM, Kipsat MJ and Serem AK. (2005). Bean varietal preference in East African markets and its implications to breeding. African Crop Science Conference Proceedings, 7, 803-805.

[12] Birachi EA, Ochieng J, Wozemba D, Ruraduma C, Niyuhire MC and Ochieng D. (2011). Factors influencing smallholder farmers' bean production and supply to market in Burundi. African Crop Science Journal, 19(4), 335342 .

[13] Mauyo LW, Okalebo JR, Kirby RA, Buruchara R, Ugen M and Musebe RO. (2007).Legal and institutional constraints to Kenya -Uganda cross-border bean marketing. African Journal of Agricultural Research, 2(11), 518-582.

[14] Chirwa RM, Aggarwal vas D, Phiri MA and Mwenda RA. (2007). Experiences in implementing the bean seed strategy in Malawi. Journal of Sustainable Agriculture, 29(27), 43-69.

[15] Guri A. (1983). Attempts to elucidate the genetic control of ozone sensitivity in seedlings of Phaseolus vulgaris L. Canadian Journal of Plant Science, 63(3), 727-731.

[16] Dixon JL, Stringer LC and Challinor AJ. (2014). Farming system evolution and adaptive capacity: insights for adaptive support. Resources, 3, 182-214.

[17] Gichangi, EM, Gatheru M, Njiru EN, Mungube EO, Wambua JM and Wamuongo JW. (2015). Assessment of climate variability and change in semi-arid Eastern Kenya. Climatic Change, 130, 287-297.

[18] Martin JH. (2004). Whiteflies of Belize (Hemiptera: Aleyrodidae). Part 1-introduction and account of the subfamily Aleurodicinae Quaintance \& Baker. Moscas blancas de Belice (Hemiptera: Aleyrodidae). Parte 1introducción y descripción de la subfamilia Aleurodicinae Quaintance \& Baker. Zootaxa, (681), 1-119.

[19] Navas-Castillo J, Fiallo-Olive E and Sanchez-Campos S. (2011). Emerging virus diseases transmitted by whiteflies.Annual Review of Phytopathology, 49, 219-248.

[20] Thompson WMO. (2011). The whitefly, Bemisiatabaci (Homoptera: Aleyrodidae) interaction with Geminivirusinfected host plants. Springer: Houten, The Netherlands.

[21] Smith HA, Seijo ET, Vallad EG, Peres AN and Druffel LK. (2015). Evaluating weeds as hosts of tomato yellow leaf curl virus. Environmental Entomology, 44, 1101-1107.

[22] Martin JM. (1987). An identification guide to common whitefly pest species of the World (Homoptera: Aleyrodidae). Tropical Pest Management, 33, 298-322.

[23] Lating DR, Jones PG and Davis HC. (1984). Common bean (Phaseolus vulgaris L.): The physiology of tropical field crops. In: Goldsmith PR and Fisher NM. (eds.). John Wiley, New York, USA, 305-353.

[24] Uebersax MA and Occena LG. (1991). Composition and nutritive value of dry edible beans: commercial and world food relief application. Michigan Dry Bean Digest, 15 (5), 3-12.

[25] Abate T and Ampofo JKO. (1996). Insect pests of common bean in Africa: Their ecology and management. Annual Reports of the Laboratory of Entomology, 41, 45-75.

[26] Otsyula RM. (1994). The status for bean production and research in Kenya. Breeding for disease resistance with emphasis on durability. In: Danial D. L. (ed). Proceedings for Regional Workshop for eastern, central and southern Africa, Nairobi, Kenya.2-6 ${ }^{\text {th }}$ October 1994. Ministry for Dev. Cop. (DGIS). Netherlands, 114-119.

[27] Karkashian J. (2011). Begomo viruses associated with bean golden mosaic disease in Nicaragua. Journal of Phytopathology, 95(8), 901-906.

\section{How to cite this article}

Kamonzo JK, Mutisya DL, Muli BK and Nguluu SN. (2018). Comparative whitefly vector density and bean disease incidence on local and hybrid varieties in semi-arid Kenya. GSC Biological and Pharmaceutical Sciences, 5(3), 46-53. 